\title{
CARMing down the SINEs of anarchy: two paths to freedom from paraspeckle detention
}

\author{
Reyad A. Elbarbary ${ }^{1,2}$ and Lynne E. Maquat ${ }^{1,2}$ \\ ${ }^{1}$ Department of Biochemistry and Biophysics, School of Medicine and Dentistry, University of Rochester, Rochester, New York \\ 14642, USA; ${ }^{2}$ Center for RNA Biology, University of Rochester, Rochester, New York 14642, USA
}

\begin{abstract}
A subset of messenger RNAs (mRNAs) that contain inverted Alu elements in their $3^{\prime}$ untranslated region are inefficiently exported to the cytoplasm and retained in subnuclear bodies called paraspeckles. The arginine methyltransferase CARM1 (coactivator-associated arginine methyltransferase 1) promotes the nuclear export of these mRNAs by methylating the paraspeckle component $\mathrm{p} 54^{\mathrm{nrb}}$, which reduces the binding of $\mathrm{p} 54^{\mathrm{nrb}}$ to the inverted Alu elements, and down-regulating synthesis of another paraspeckle component, the long noncoding RNA NEAT1, which inhibits paraspeckle formation.
\end{abstract}

To serve as templates for protein synthesis, messenger RNAs (mRNAs) must be exported from the nucleus in which they are synthesized to the cytoplasm, where their translation occurs. In many human cell types, however, a subset of mRNAs is retained within nuclei and therefore is only inefficiently translated. One feature common to a number of these retained mRNAs is a $3^{\prime}$ untranslated region (UTR) inverted repeat of Alu elements (IRAlus) that forms a hairpin structure containing an imperfectly base-paired stem as long as 300 nucleotides. Alu elements are primate-specific short interspersed elements (SINEs). The degree to which different $3^{\prime}$ UTR IRAlus-containing mRNAs (IRAlus mRNAs) are retained within nuclei varies depending on the particular mRNA and the cell type in which it is expressed. In addition to the widely used process of alternative RNA $3^{\prime}$ end formation that can determine whether a transcript contains a $3^{\prime}$ UTR IRAlus, regulatory mechanisms responsible for variability in the nuclear retention of IRAlus mRNAs exist but are incompletely understood. In the March 15, 2015, issue of Genes \& Development, $\mathrm{Hu}$ et al. (2015) revealed that the nuclear export of IRAlus mRNAs that can enter nuclear paraspeckles is regulated by a multifunctional arginine methylase.

[Keywords: paraspeckles; p54 ${ }^{\mathrm{nrb}}$; nuclear retention; CARM1; NEAT1] Corresponding author: lynne_maquat@urmc.rochester.edu Article is online at http://www.genesdev.org/cgi/doi/10.1101/gad.261438. 115 .
Paraspeckles are subnuclear sites of IRAlus mRNA retention (Chen et al. 2008). These nonmembrane-delimited bodies are built around the long noncoding RNA NEAT1 (which is essential for paraspeckle integrity) and contain multiple RNA-binding proteins that include non-POU domain-containing octamer binding (p54 ${ }^{\mathrm{nrb}}$ or NonO), p5 $4^{\mathrm{nrb}}$-associated splicing factor proline/glutamine-rich (PSF or SFPQ), and paraspeckle component 1 (PSPC1) (Fox et al. 2002; Prasanth et al. 2005). In search of new substrates for the coactivator-associated arginine methyltransferase 1 (CARM1; also called PRMT4), Hu et al. (2015) used mass spectrometry and identified $\mathrm{p} 54^{\mathrm{nrb}}$ in acid-extracted histones from the nuclei of $\mathrm{CARM1}^{-/-}$mouse embryonic fibroblasts as a substrate for in vitro methylation by Escherichia coli-produced GST-tagged CARM1. Using protein immunostaining and RNA in situ hybridization, p54 ${ }^{\text {nrb }}$ and CARM1 were subsequently shown to colocalize within HeLa cell nuclei largely to NEAT1-defined paraspeckles. CARM1-mediated methylation within and near the coiled-coil domain of $\mathrm{p} 54^{\mathrm{nrb}}$ reduced $\mathrm{p} 54^{\mathrm{nrb}}$ binding to dsRNAs in vitro and to $3^{\prime}$ UTR IRAlus reporter and cellular mRNAs in HeLa cells. Additionally, replacing endogenous CARM1 with a catalytically inactive variant or replacing endogenous p5 $4^{\text {nrb }}$ with a variant in which three sites of CARM1-mediated methylation were mutated from arginine to lysine enhanced the retention of $3^{\prime}$ UTR IRAlus reporter and cellular mRNAs within nuclei.

Remarkably, a second path by which CARM1 mediates the retention of reporter and cellular IRAlus mRNAs in paraspeckles was uncovered when the investigators pursued evidence from others that CARM1 associates with different classes of transcription factors. Assays of the abundance of NEAT1 in CARM1 knockdown HeLa cells revealed abnormally more NEAT1 and paraspeckles, and chromatin immunoprecipitations demonstrated that CARM1 is enriched at the NEAT1 promoter. Promoter-

(C) 2015 Elbarbary and Maquat This article is distributed exclusively by Cold Spring Harbor Laboratory Press for the first six months after the full-issue publication date (see http://genesdev.cshlp.org/site/misc/ terms.xhtml). After six months, it is available under a Creative Commons License (Attribution-NonCommercial 4.0 International), as described at http://creativecommons.org/licenses/by-nc/4.0/. 

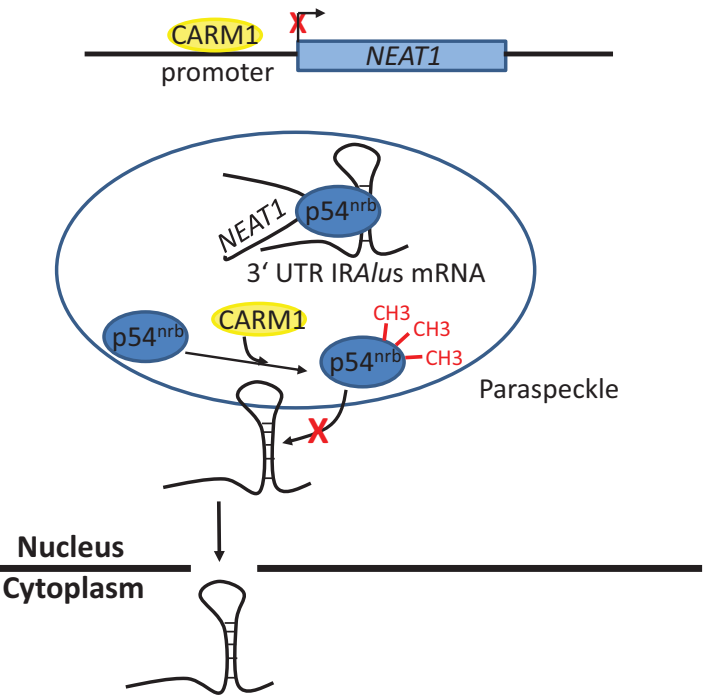

Figure 1. CARM1 promotes the nuclear export of $3^{\prime}$ UTR IRAlus mRNAs by two mechanisms. The arginine methylase CARM1 enhances the nuclear export of a subset of $3^{\prime}$ UTR IRAlus mRNAs that are retained in nuclear paraspeckles by methylating the coiled-coil domain of the paraspeckle component p54 $4^{\mathrm{nrb}}$, which reduces the binding of p54 ${ }^{\mathrm{nrb}}$ to $3^{\prime}$ UTR IRAlus mRNAs. Additionally CARM1 binding to the promoter of the NEAT1 gene somehow down-regulates synthesis of the paraspeckle long noncoding RNA NEAT1, which reduces paraspeckle formation.

bound CARM1 down-regulated NEAT1 gene transcription so as to reduce the number of paraspeckles and thereby promote IRAlus mRNA export to the cytoplasm. Thus, CARM1 "frees" IRAlus mRNAs from paraspeckle "detention" via two paths: methylating p54 ${ }^{\text {nrb }}$ and down-regulating NEAT1 gene transcription (Fig. 1). Stimulating NEAT1 synthesis and paraspeckle formation by exposing HeLa cells to poly(I:C), which binds to toll-like receptor 3 and induces an antiviral response (Imamura et al. 2014), was accompanied by reduced CARM1 binding to the NEAT1 promoter. In addition, poly(I:C) treatment reduced CARM1 localization to paraspeckles so as to decrease $\mathrm{p} 54^{\mathrm{nrb}}$ methylation. As a consequence, poly(I:C) enhanced the nuclear retention of IRAlus mRNA. The mechanism by which poly(I:C) influences cellular CARM1 localization and function remains to be studied.

Data presented by $\mathrm{Hu}$ et al. (2015) raise many interesting questions. As examples, what is the structural explanation for the finding that CARM1-mediated methylation of $\mathrm{p} 54^{\mathrm{nrb}}$ inhibits $\mathrm{p} 54^{\mathrm{nrb}}$ binding to dsRNA, and how does CARM1 down-regulate NEAT1 synthesis? Another conundrum is why different transcripts with seemingly similar 3' UTR IRAlus manifest distinctly different subcellular localizations whereby some are efficiently retained in nuclear paraspeckles while others are largely cytoplasmic and either translationally active or translationally silent (Chen et al. 2008; Hundley and Bass 2010; Capshew et al. 2012; Fitzpatrick and Huang 2012; Elbarbary et al. 2013). Competition among the various dsRNA-binding proteins that differentially affect the metabolism of different IRAlus mRNAs undoubtedly plays a role in regulating IRAlus mRNAs on top of which might be layered yet to be discovered post-translational modifications that alter the affinities of dsRNA-binding proteins for IRAlus. For example, it is already known that IRAlus are major binding sites for the dsRNA-binding protein Staufen 1 (STAU1) (Elbarbary et al. 2013; Ricci et al. 2014). When STAU1 outcompetes p5 $4^{\mathrm{nrb}}$ binding to one class of 3' UTR IRAlus, then nuclear retention of the affected IRAlus mRNAs is inhibited, and their export to the cytoplasmic is enhanced (Elbarbary et al. 2013). In the cytoplasm, 3' UTR IRAlus have the potential to bind and activate another dsRNA-binding protein, the translational inhibitor protein kinase R (PKR), making 3' UTR IRAlus negative regulators of mRNA translation both in cis and in trans (Elbarbary et al. 2013; Kim et al. 2014). STAU1 also competes with PKR for binding to $3^{\prime}$ UTR IRAlus so as to alleviate translational repression (Elbarbary et al. 2013). The segregation of nuclear-retained IRAlus mRNAs away from cytoplasmic PKR during interphase complements the binding of STAU1 to preclude PKR binding to $3^{\prime}$ UTR IRAlus that would otherwise inhibit cellular translation (Elbarbary et al. 2013; Kim et al. 2014). In contrast, dissolution of the nuclear membrane during mitosis removes the boundaries between nuclear-retained IRAlus mRNAs and cytoplasmic PKR, resulting in PKR activation that is necessary for regulated mitosis (Kim et al. 2014).

In summary, genes harboring the potential to encode one or more mRNA isoforms that contain a $3^{\prime}$ UTR IRAlus can be regulated by specialized mechanisms that depend on the efficiencies with which their product mRNAs are retained within the nucleus versus exported to the cytoplasm with or without the concomitant possibility of their translation. These efficiencies, which vary during mitosis and undoubtedly in other cellular states as a means of maintaining cellular homeostasis, are dictated by the potential binding of multiple proteins to $3^{\prime}$ UTR IRAlus within both the nucleus and the cytoplasm. Binding is likely to be regulated by post-translational modifications beyond the CARM1-mediated methylation of $\mathrm{p} 54^{\mathrm{nrb}}$ described by Hu et al. (2015). Also, while IRAlus are known to be major sites of A-to-I editing and while Ato-I editing does not appear to regulate $\mathrm{p} 54^{\text {nrb }}$ or STAU1 binding to those IRAlus studied (Elbarbary et al. 2013), editing may influence the binding of other IRAlus factors. It is clear that there is still much to learn about how IRAlus influence mRNA metabolism.

\section{Acknowledgments}

Research in the Maquat laboartory on SINEs is supported by National Institutes of Health grant R37 074593 to L.E.M.

\section{References}

Capshew CR, Dusenbury KL, Hundley HA. 2012. Inverted Alu dsRNA structures do not affect localization but can alter translation efficiency of human mRNAs independent of RNA editing. Nucleic Acids Res 40: 8637-8645. 
Chen LL, DeCerbo JN, Carmichael GG. 2008. Alu element-mediated gene silencing. EMBO J 27: 1694-1705.

Elbarbary RA, Li W, Tian B, Maquat LE. 2013. STAU1 binding 3' UTR IRAlus complements nuclear retention to protect cells from PKR-mediated translational shutdown. Genes Dev 27: 1495-1510.

Fitzpatrick T, Huang S. 2012. 3'-UTR-located inverted Alu repeats facilitate mRNA translational repression and stress granule accumulation. Nucleus 3: 359-369.

Fox AH, Lam YW, Leung AK, Lyon CE, Andersen J, Mann M, Lamond AI. 2002. Paraspeckles: a novel nuclear domain. Curr Biol 12: 13-25.

Hu S-B, Xiang J-F, Li X, Xu Y, Xue W, Huang M, Wang CC, Sagum CA, Bedford MT, Yang L, et al. 2015. Protein arginine methyltransferase CARM1 attenuates the paraspeckle-mediated nuclear retention of mRNAs containing IRAlus. Genes Dev 29: 630-645.
Hundley HA, Bass BL. 2010. ADAR editing in double-stranded UTRs and other noncoding RNA sequences. Trends Biochem Sci 35: 377-383.

Imamura K, Imamachi N, Akizuki G, Kumakura M, Kawaguchi A, Nagata K, Kato A, Kawaguchi Y, Sato H, Yoneda M, et al. 2014. Long noncoding RNA NEAT1-dependent SFPQ relocation from promoter region to paraspeckle mediates IL8 expression upon immune stimuli. Mol Cell 53: 393-406.

Kim Y, Lee JH, Park JE, Cho J, Yi H, Kim VN. 2014. PKR is activated by cellular dsRNAs during mitosis and acts as a mitotic regulator. Genes Dev 28: 1310-1322.

Prasanth KV, Prasanth SG, Xuan Z, Hearn S, Freier SM, Bennett CF, Zhang MQ, Spector DL. 2005. Regulating gene expression through RNA nuclear retention. Cell 123: 249-263.

Ricci EP, Kucukural A, Cenik C, Mercier BC, Singh G, Heyer EE, Ashar-Patel A, Peng L, Moore MJ. 2014. Staufen1 senses overall transcript secondary structure to regulate translation. Nat Struct Mol Biol 21: 26-35. 


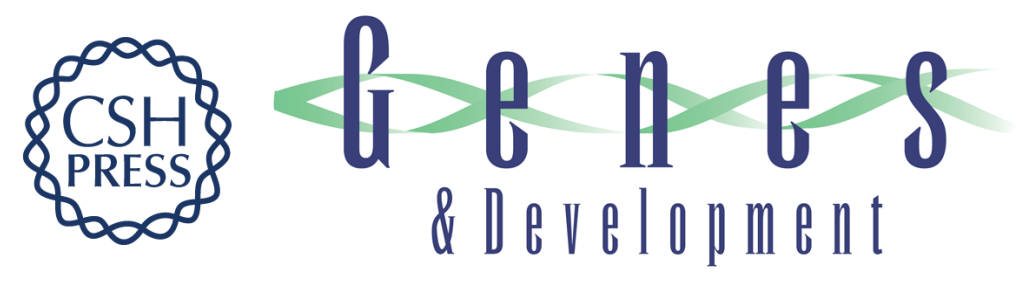

\title{
CARMing down the SINEs of anarchy: two paths to freedom from paraspeckle detention
}

Reyad A. Elbarbary and Lynne E. Maquat

Genes Dev. 2015, 29:

Access the most recent version at doi:10.1101/gad.261438.115

\begin{abstract}
Related Content Protein arginine methyltransferase CARM1 attenuates the paraspeckle-mediated nuclear retention of mRNAs containing IRAlus

Shi-Bin Hu, Jian-Feng Xiang, Xiang Li, et al.

Genes Dev. March , 2015 29: 630-645

References This article cites 11 articles, 4 of which can be accessed free at:

http://genesdev.cshlp.org/content/29/7/687.full.html\#ref-list-1

Articles cited in:

http://genesdev.cshlp.org/content/29/7/687.full.html\#related-urls

Creative This article is distributed exclusively by Cold Spring Harbor Laboratory Press for the first

Commons six months after the full-issue publication date (see

License http://genesdev.cshlp.org/site/misc/terms.xhtml). After six months, it is available under a Creative Commons License (Attribution-NonCommercial 4.0 International), as described at http://creativecommons.org/licenses/by-nc/4.0/.

Email Alerting Receive free email alerts when new articles cite this article - sign up in the box at the top Service right corner of the article or click here.
\end{abstract}

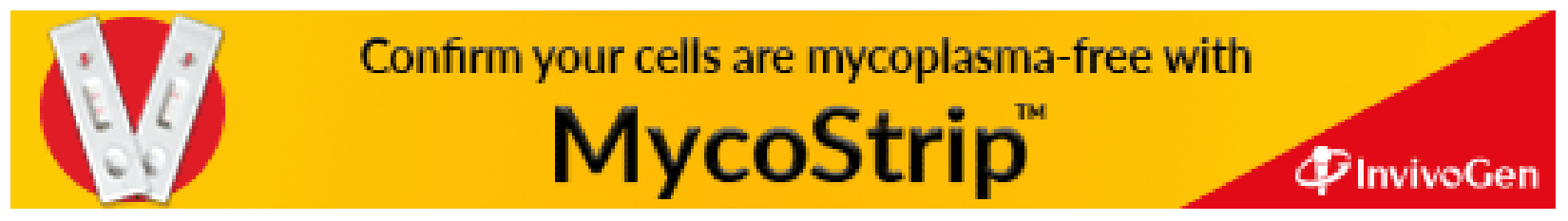

